Annales Geophysicae (2001) 19: 179-188 (C) European Geophysical Society 2001

\title{
The UV aurora and ionospheric flows during flux transfer events
}

\author{
D. A. Neudegg ${ }^{1, *}$, S. W. H. Cowley ${ }^{1}$, K. A. McWilliams ${ }^{1}$, M. Lester ${ }^{1}$, T. K. Yeoman ${ }^{1}$, J. Sigwarth ${ }^{2}$, G. Haerendel ${ }^{3}$, W. \\ Baumjohann $^{3}$, U. Auster ${ }^{4}$, K.-H. Fornacon ${ }^{4}$, and E. Georgescu ${ }^{5}$ \\ ${ }^{1}$ Department of Physics and Astronomy, Leicester University, Leicester LE1 7RH, UK \\ ${ }^{2}$ Department of Physics, University of Iowa, USA \\ ${ }^{3}$ Max-Planck Institut für Extraterrestrische Physik, Garching, Germany \\ ${ }^{4}$ Technische Universität von Braunschweig, Braunschweig, Germany \\ ${ }^{5}$ Institute of Space Science, Bucharest, Romania \\ *Now at: Rutherford-Appleton Laboratory, Oxfordshire OX11 0QX, UK
}

Received: 24 July 2000 - Revised: 11 December 2000 - Accepted: 12 December 2000

\begin{abstract}
Far Ultra Violet (FUV) signatures in the polar ionosphere during a period of magnetopause reconnection are compared with ionospheric flows measured in the cusp 'throat' and dusk cell by the CUTLASS Hankasalmi HF radar. Regions of peak FUV emission in the $130.4 \mathrm{~nm}$ and $135.6 \mathrm{~nm}$ range, observed by the Polar spacecraft's VIS Earth Camera, consistently lie at the turning point of the flows from the dusk cell, poleward into the throat, and at the equatorward edge of the region of high and varied radar spectral-width associated with the cusp. The Equator-S spacecraft was near the magnetopause at the time of the ionospheric observations and geomagnetically conjugate with the region of ionosphere observed by the radar. Flux transfer events (FTEs), suggestive of bursty reconnection between the IMF and geomagnetic fields, were observed by Equator-S prior to and during the periods of high FUV emission. Enhanced poleward ionospheric flow velocities in the polar cusp region, previously shown to be associated with bursty reconnection, consistently lie poleward of the enhanced FUV optical feature. The enhanced optical feature is consistent with the expected position of the largest upward region 1 field-aligned current, associated with electron precipitation, on the dusk edge of the merging gap. The optical feature moves duskward and equatorward during the course of the reconnection sequence, consistent with expansion of the merging line and the polar cap with newly added open magnetic flux by the FTEs. The DMSP F14 spacecraft passed through the enhanced FUV region and measured strong, structured electron precipitation far greater than in the adjacent regions.
\end{abstract}

Key words. Magnetospheric physics (current systems; mag-

Correspondence to: T. K. Yeoman

(tim.yeoman@ion.le.ac.uk) netopause, cusp and boundary layers; magnetosphere-ionosphere interactions)

\section{Introduction}

The effect of transient dayside reconnection of the interplanetary and geomagnetic fields on the polar ionosphere has been a prominent theme in magnetosphere-ionosphere coupling since its first observation by Elphic et al. (1990) (see e.g. Kan et al., 1996; Provan et al., 1998; Milan et al., 2000). Cowley et al. (1991) presented in detail the expected effects on ionospheric convection of both steady and transient dayside reconnection. Cowley and Lockwood (1992) refined predictions of the excitation and decay of ionospheric flows induced by day- and nightside reconnection including the azimuthal effects of IMF $B_{y}$. Ultimately, such ionospheric flows are driven by field-aligned-currents (FACs) (e.g. Iijima and Potemra, 1978) which transmit energy and stress from the magnetosheath to the polar ionosphere (e.g. Glassmeier and Stellmacher, 1996; Wright, 1996; Cowley, 2000).

$\mathrm{HF}$ radars have observed high velocity flow channels in the cusp ionosphere, termed flow channel events (FCEs), that were assumed to be the response to transient reconnection (Pinnock et al. 1993, 1995; Rodger and Pinnock 1997). Quasi-periodic sequences of such events have also been termed pulsed ionospheric flows (PIFs), and the spatial extent of these events, their flow orientation, MLT occurrence, dependence on IMF orientation and repetition frequencies have been extensively examined (Provan et al., 1998, 1999; Provan and Yeoman, 1999; Milan et al., 1999; McWilliams et al., 2000). Neudegg et al. (1999) presented a single case study of a southward turning of the IMF, a coincident episode of 
flux transfer at the magnetopause (a flux transfer event or FTE) observed by the Equator-S spacecraft, and the resultant flow channel event observed in the conjugate ionosphere by the CUTLASS Hankasalmi HF radar. A survey near the magnetopause with Equator-S and in the polar ionosphere with the network of northern hemisphere SuperDARN radars showed the onset of enhanced velocity flow channels in the cusp ionosphere to be associated with the occurrence of FTEs at a high significance level (Neudegg et al., 2000).

Optical signatures associated with dayside reconnection have been extensively investigated from the ground in the visible wavelengths of $630.0 \mathrm{~nm}$ and $557.7 \mathrm{~nm}$, associated with auroral activity (e.g. Lockwood et al., 1989, 1993, 1995; Sandholt et al., 1996; Øieroset et al., 1996; Mende et al., 1998). Generally these studies show equatorward motion of the cusp aurora during reconnection and a sequence of distinct poleward moving auroral forms (PMAFs), the motion of which resembles the flows measured by HF radar. Indeed the occurrence rates of FTEs, PMAFs and PIFs has been shown to be very similar (McWilliams et al., 2000). The availability of space-based measurements in the visible and UV wavelengths, from platforms such as Polar, has made available global views of emissions not available from the ground and the possibility of observing processes in wavelengths that are screened from ground observation by atmospheric absorption (e.g. Milan et al., 2000).

In this paper, we will examine the relationship between a region of enhanced UV emission observed by the Polar VIS Earth Camera in a wavelength range not often employed in dayside reconnection studies, and the geometry of polar ionospheric flows in the dusk cell and cusp throat, as observed by the Hankasalmi SuperDARN HF radar in Finland. The enhanced UV region occurs during a period of dayside reconnection in the interval 1015-1050 UT on 4 January 1998 when the Equator-S spacecraft observed FTEs near the magnetopause and was geomagnetically conjugate with the radar field-of-view (Neudegg et al., 1999).

\section{Instrumentation}

\subsection{Polar ionosphere: SuperDARN Hankasalmi HF radar}

Details of the SuperDARN HF radars are given in Greenwald et al. (1995) and the CUTLASS systems at Hankasalmi in Finland and Pykkvibær in Iceland by Milan et al. (1997). During the Equator-S geomagnetic conjunction with CUTLASS on 4 January 1998, a special high space- and timeresolution scan mode was run with $30 \mathrm{~km}$ range gates and a $2 \mathrm{~s}$ dwell time for each beam, resulting in a $32 \mathrm{~s}$ sweep over the 16 beams (from beam 15 on the east of the field-of-view (f-o-v) to beam 0 on the west for the Hankasalmi radar). The geomagnetic field lines from Equator-S have been mapped to the ionosphere using the Tsyganenko 89a model for the actual $K p$ value of 0 . This model predicts the spacecraft to have been on open field lines during the interval 0900-1300 UT. The magnetometer data show that Equator-S was located on magnetospheric field lines until $\sim 1034$ UT, when it entered the magnetosheath. The continuation of the predicted geomagnetically conjugate ionospheric point from 0900 UT along a smooth arc places the footprint of Equator-S during the FTE observations near the far ranges of the radar in beams $0-6$ on the western side of the f-o-v. The altitude of the radar backscatter is assumed to be between 300 and 350 $\mathrm{km}$. During this interval, Hankasalmi was the only SuperDARN radar to observe ionospheric scatter in either hemisphere.

\subsection{Polar ionosphere: Polar VIS Earth camera}

The Visible Imaging System (VIS) (Frank et al., 1995) on the Polar spacecraft comprises three camera systems, one of which is the Earth Camera. The VIS Earth Camera has a sufficiently large field-of-view to provide images of an entire hemisphere during much of the spacecraft's orbit and is used as a global survey instrument for the other higher resolution cameras in the VIS suite. The Earth Camera operates in the 124-149 $\mathrm{nm}$ range and mainly registers the electron precipitation induced O I auroral transitions at $130.4 \mathrm{~nm}$ and $135.6 \mathrm{~nm}$ in the far ultraviolet (FUV) range (e.g. Feldman and Gentieu, 1982; Meier et al., 1982; Meier and Strickland, 1991). The emissions are excited by electron precipitation in the $1-5 \mathrm{keV}$ range, but the intensities observed above the ionosphere at $5 \mathrm{keV}$ precipitation energies may be significantly less than those from $1 \mathrm{keV}$ due to scattering and reabsorption of the emissions. The peak intensity for $130.4 \mathrm{~nm}$ and $135.6 \mathrm{~nm}$ emissions are in the $140-180 \mathrm{~km}$ altitude range and production rates peak at $100-130 \mathrm{~km}$, determined by in situ rocket measurements (Meier et al., 1982). Each VIS exposure is 32.5 seconds and the time between exposures is 4 minutes. The spatial resolution of the camera in the data presented here, when the spacecraft was at $8.4 R_{E}$, near apogee, was $\sim 75 \mathrm{~km}$ (twice that of the radar range gates). Polar was also located on the nightside so the dayside features suffered from some limb stretching effects which further reduced the spatial resolution.

\subsection{Magnetopause: Equator-S spacecraft}

The Equator-S spacecraft was launched on 2 December 1997 into an initial geostationary transfer orbit, and was then boosted to an elliptical orbit with apogee close to the magnetopause on 11 December 1997. The mission is described in detail by Haerendel et al. (1999). The FTE sequence described in this paper was observed by the magnetometer experiment (Fornacon et al., 1999) near apogee at $\sim 1020$ UT $(\sim 0910$ MLT) on 4 January 1998, when the spacecraft was $\sim 11.3 R_{E}$ from Earth at GSM $(X, Y, Z)=(8,7,4) R_{E}$. This occurred during the instrument's commissioning phase when only the magnetometer was continuously operating, at a 64 $\mathrm{Hz}$ sampling rate, although spin-averaged $1.5 \mathrm{~s}$ resolution data is used here. The spacecraft trajectory for this period is described in Neudegg et al. (1999). 

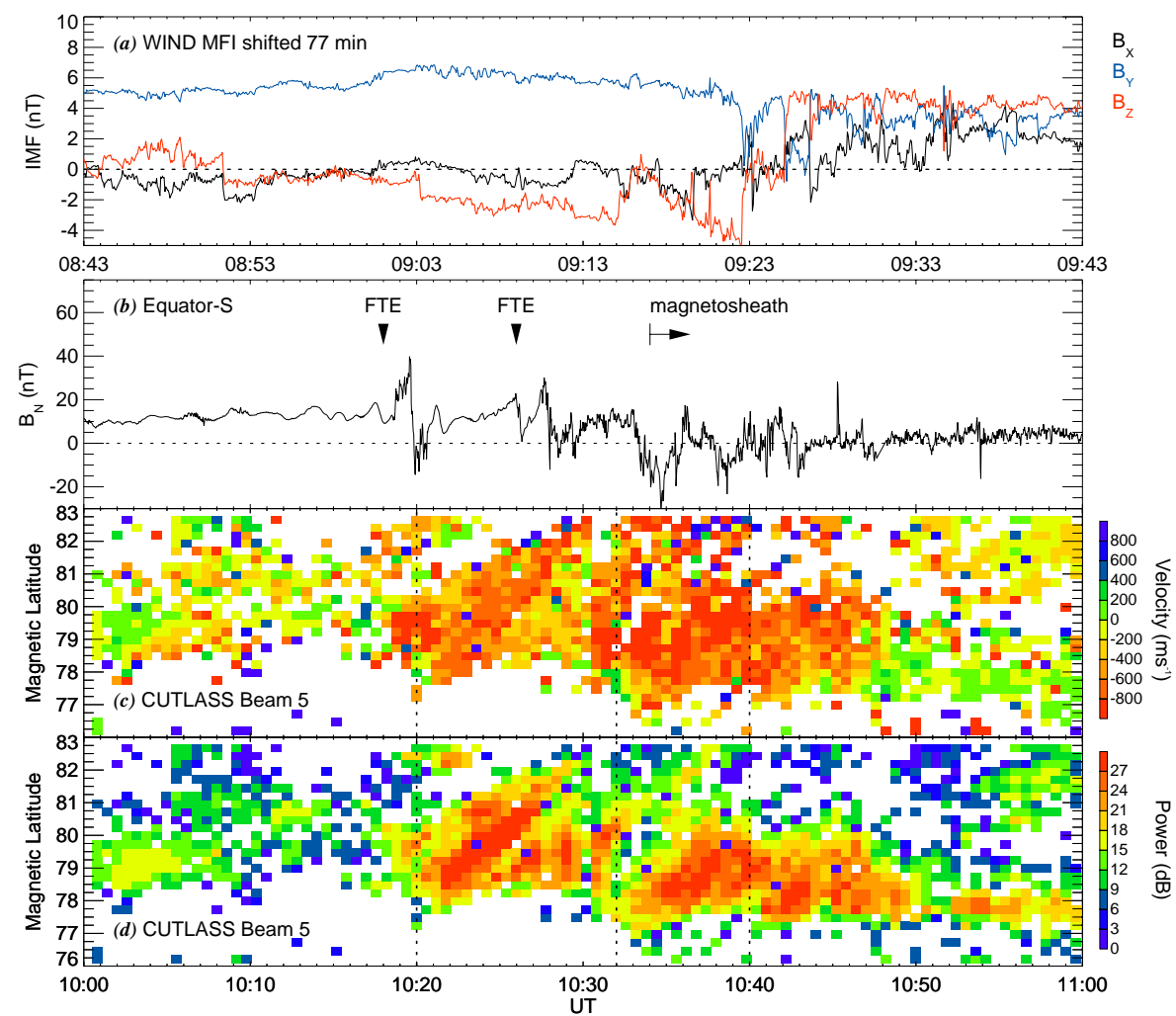

Fig. 1. (a) The Wind upstream IMF GSM $B_{x}, B_{y}$ and $B_{z}$ component data during the interval under study. The data is timelagged by 77 min relative to the panels presented below (b) Equator$\mathrm{S}$ boundary normal component magnetic field from the magnetopause region (c) Colour-coded (positive (blue) velocities are toward the radar, negative (red) velocities away from the radar) CUTLASS Hankasalmi beam 5 line-ofsight velocity data as a function of magnetic latitude (d) Colour-coded CUTLASS Hankasalmi beam 5 backscattered power data as a function of magnetic latitude. Times of FTE-associated enhanced ionospheric flow onsets are marked with dashed vertical lines in panels $\mathrm{c}$ and $\mathrm{d}$.

\subsection{DMSP spacecraft particle signatures}

The DMSP (Defense Meteorological Satellite Program) is a series of spacecraft with upward looking charged particle flux and energy detectors amongst its complement of instruments. The particle spectra from these instruments have been used to determine the location and statistical time variation of high latitude plasma regions of the magnetosphere near 830 $\mathrm{km}$ altitude (e.g. Newell and Meng, 1992). In this study, the DMSP F14 spacecraft was used as it passed along the equatorward edge of the region of high FUV intensity, observed by the Polar VIS Earth Camera. The spacecraft is three-axis stabilised with the particle detectors pointing towards the local zenith, directly away from the Earth, and having a fairly narrow field of view of $8^{\circ}$. Electrostatic analysers measure electron and ion energies and fluxes from $32 \mathrm{eV}$ to $30 \mathrm{keV}$ in 20 logarithmically based steps (Hardy et al., 1985).

\section{Results}

\subsection{Reconnection sequence overview}

The reconnection sequence occured during the period 10001100 UT on 4 January 1998, and is summarised in Fig. 1. Figure 1a presents the IMF measured by the Wind spacecraft magnetometer (Lepping et al., 1995), time lagged at the solar wind velocity to the bow-shock and through the magnetosheath to the sub-solar magnetopause using modelled bow shock and magnetopause positions, as described by Neudegg et al. (1999) for the same data sequence. The estimated time delay is 77 minutes with an uncertainty of the order of 5 minutes. The reference point for this timing is the sub-solar magnetopause as a first approximation for the reconnection site. A slight southward IMF turning to near $1 \mathrm{nT}$ from a low northward $(<+2 \mathrm{nT})$ configuration, observed by Wind, is estimated to reach the magnetopause at $\sim 1008$ UT. A sharp southward excursion to 2 nT reached the magnetopause at $\sim 1020$ UT. This period of extended IMF southward configuration with a positive $B_{y}$ of $5 \mathrm{nT}$ continued until a sharp excursion towards $B_{z}=0$ reached the magnetopause at $\sim 1039$ UT, and then another sharp excursion to $+4 \mathrm{nT}$ at $\sim 1042$ UT. Equator-S (Fig. 1b) was in the magnetosphere at the start of the sequence and observed a large ( 40 nT peak-to-peak amplitude) FTE onset at 1018 UT; the reconnection bulge having presumably propagated around the magnetopause to Equator-S from the azimuthally expanding reconnection point. The effects of reconnection also propagate to the polar ionosphere from the reconnection site along geomagnetic field lines at the Alfvén speed. Both propagation delays are of the order of 2-3 minutes. The first FTE is followed by a second of only slightly less magnitude at 1026 UT, just before the spacecraft enters the boundary layer at $\sim 1027$ UT, and then the magnetosheath at 1034 UT. Subsequent to this a number of possible magnetosphere reentries occured (Neudegg et al., 1999).

During the time sequence described above, the Hankasalmi radar observed a series of three line-of-sight (1-o-s) plasma velocity enhancements interpreted as flow channel events or 

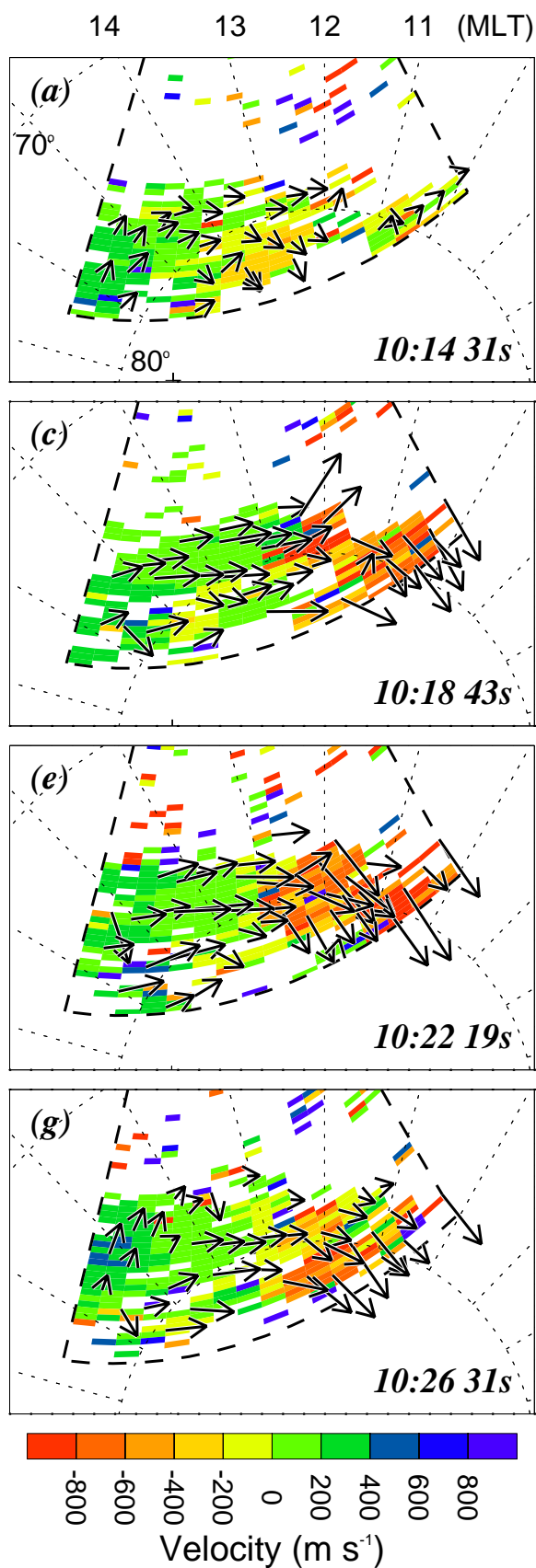
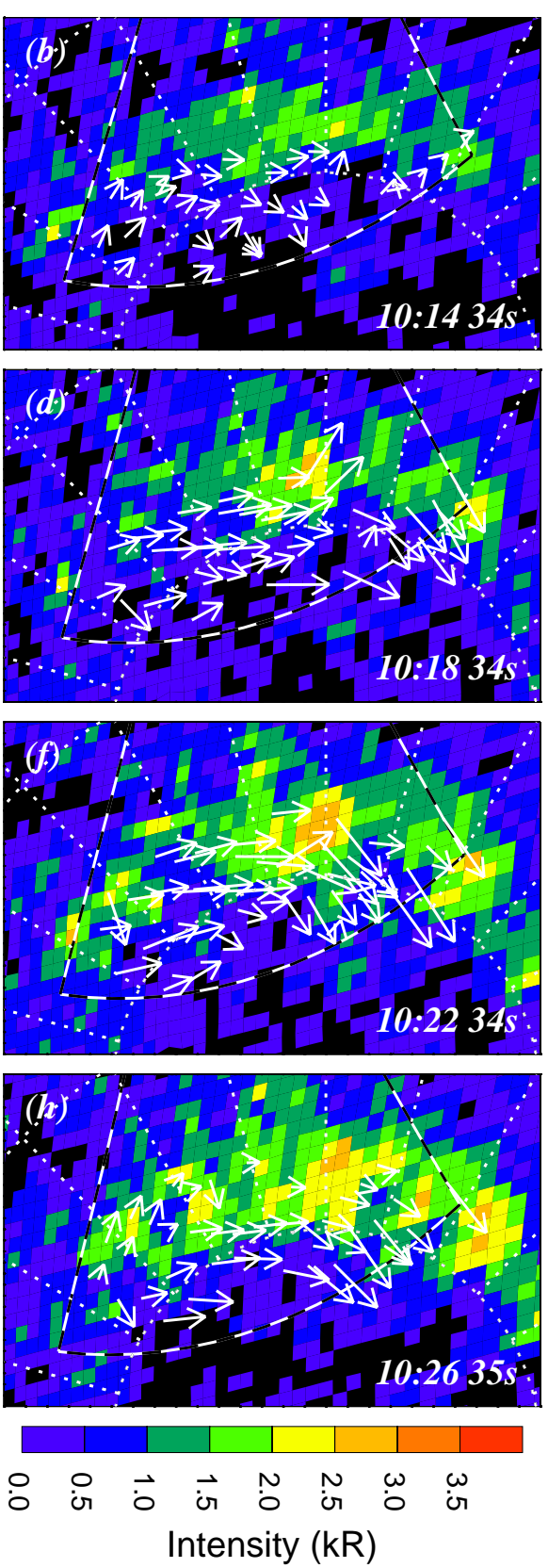

Fig. 2. Left column (a, c, e, g) CUTLASS Hankasalmi line-of-sight velocity scans for four $32 \mathrm{~s}$ scans during the interval 1014:31-1026:31 UT, in magnetic local time-magnetic latitude coordinates, with noon at the top of the panels and dusk to the left. Beamswung velocity vector estimates are overlaid. Right column (b, d, f, h) The corresponding 32.5 s Polar VIS auroral images. The beamswung vectors from panels (a, c, e, g) are overlaid for reference, as is the outline of the Hankasalmi field-of-view. Each panel is marked with the radar scan/image start time. pulsed ionospheric flows (Pinnock et al., 1993, 1995; Rodger and Pinnock, 1997; Provan et al., 1998, 1999; Provan and Yeoman, 1999, Milan et al., 1999) in beams 3 to 7. L-o$\mathrm{s}$ velocity and backscattered power in beam 5 are shown as functions of magnetic latitude and UT in Fig. 1c and d, respectively. PIFs commenced at $\sim 1020$ UT, 1032 UT and 1040 UT, and these times are marked on Fig. 1 as dashed vertical lines. The first flow channel has been shown to be associated with the 1018 UT FTE at Equator-S by Neudegg et al. (1999) and is particularly well defined in the radar data. The strong statistical association between FTEs and flow channels described in Neudegg et al. (2000) suggests the second enhanced flow may be associated with the 1026 UT FTE. Equator-S does not observe a third FTE, but as it is near apogee, the rapid entry to the sheath suggests an inward moving magnetopause may have carried the reconnection bulge earthward, away from the spacecraft. Such inferred magnetopause motion is due mainly to flux erosion as a consequence of the southward directed IMF, but also partially to solar wind dynamic pressure changes (see the discussion of Neudegg et al., 1999). The third flow channel in the ionosphere commencing at 1040 UT suggests a third FTE near 1036 UT at the magnetopause which was earthward of Equator-S. The radar backscattered power exhibits 

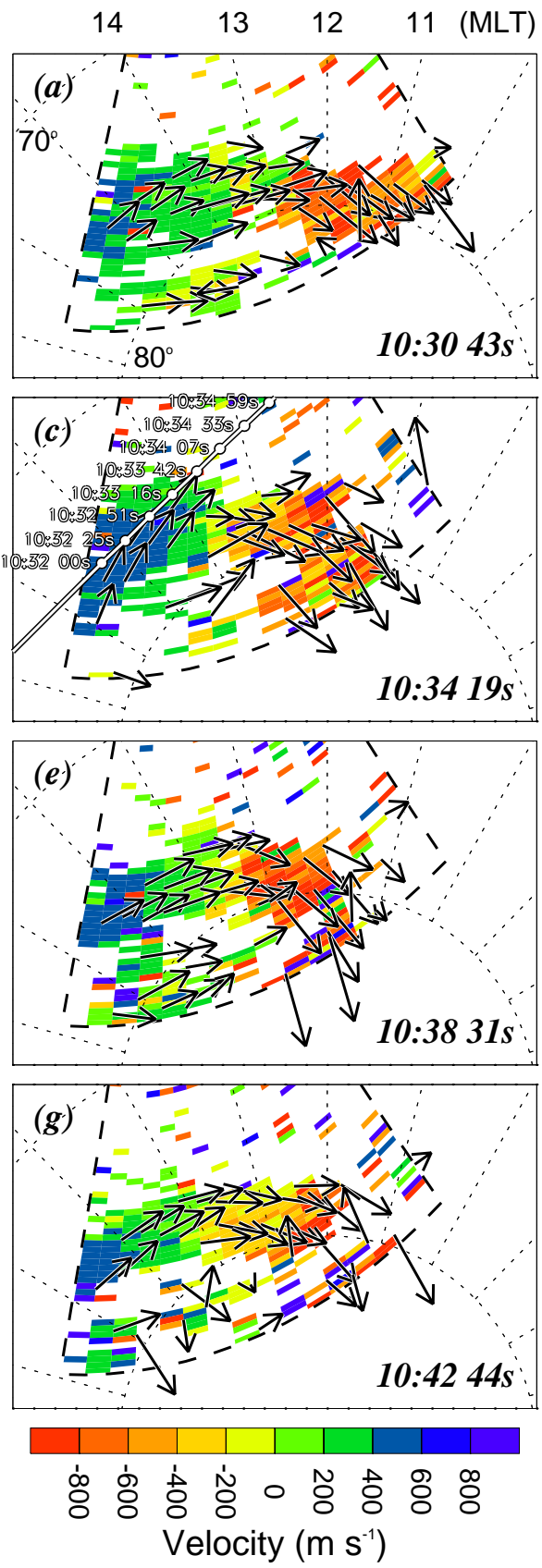
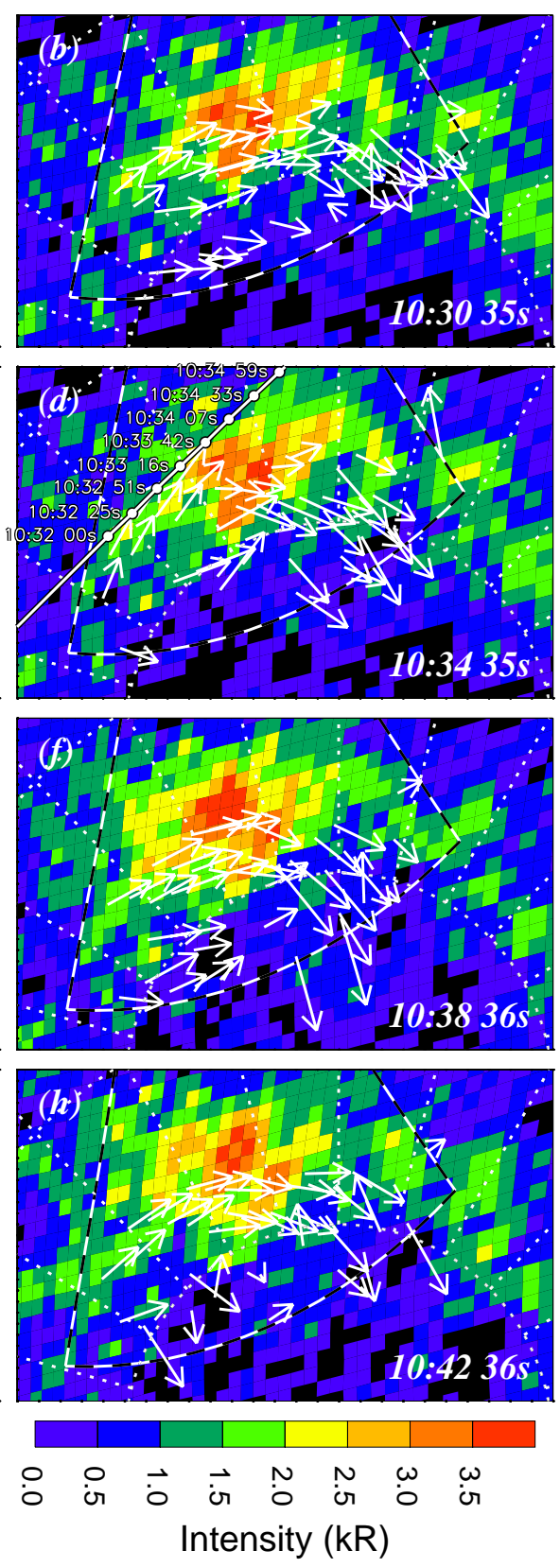

Fig. 3. CUTLASS Hankasalmi line-ofsight velocity scans and Polar VIS images for the interval 1030:43-1042:44 UT. Format as for Fig. 2. The footprint of a DMSP overpass is also shown in panels $\mathrm{c}$ and $\mathrm{d}$. enhancements co-located with the pulsed flows and of the same duration, often with greater contrast between power levels than between 1-o-s velocities. The first event begins at $78.5^{\circ}$ MLAT and the second two events begin close to $77.5^{\circ}$ MLAT, so a general equatorward motion occurs, suggesting polar cap expansion as new open flux is added by the FTEs (Cowley and Lockwood, 1992). These flows were within the region of high spectral width, which Baker et al. (1995) associated with cusp precipitation, deduced from a study of DMSP particle and radar spectra.

\subsection{HF radar and POLAR FUV observations}

The left hand side panels of Figs. 2-4 present maps of colourcoded 1-o-s velocity measured by the Hankasalmi radar for a sequence of selected scans throughout the interval, in magnetic latitude-magnetic local time coordinates. Overlaid on these scans are a number of estimates of the horizontal flow vector, calculated using a beamswinging algorithm where the flow component parallel to the L-shell is assumed constant across the scan (Villain et al., 1987; Ruohoniemi et al., 1989). The radar scans are chosen to correspond to the times of Polar VIS FUV emission images with intensities in kilo-Raleigh, which are presented in corresponding panels on 

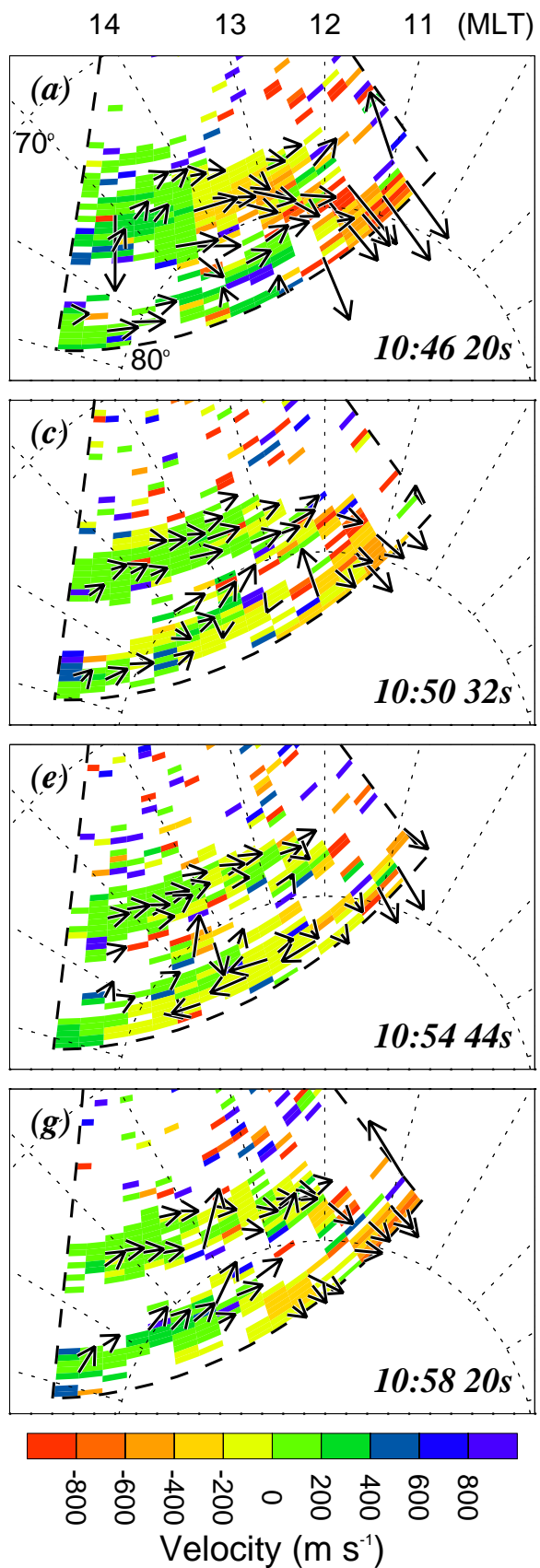
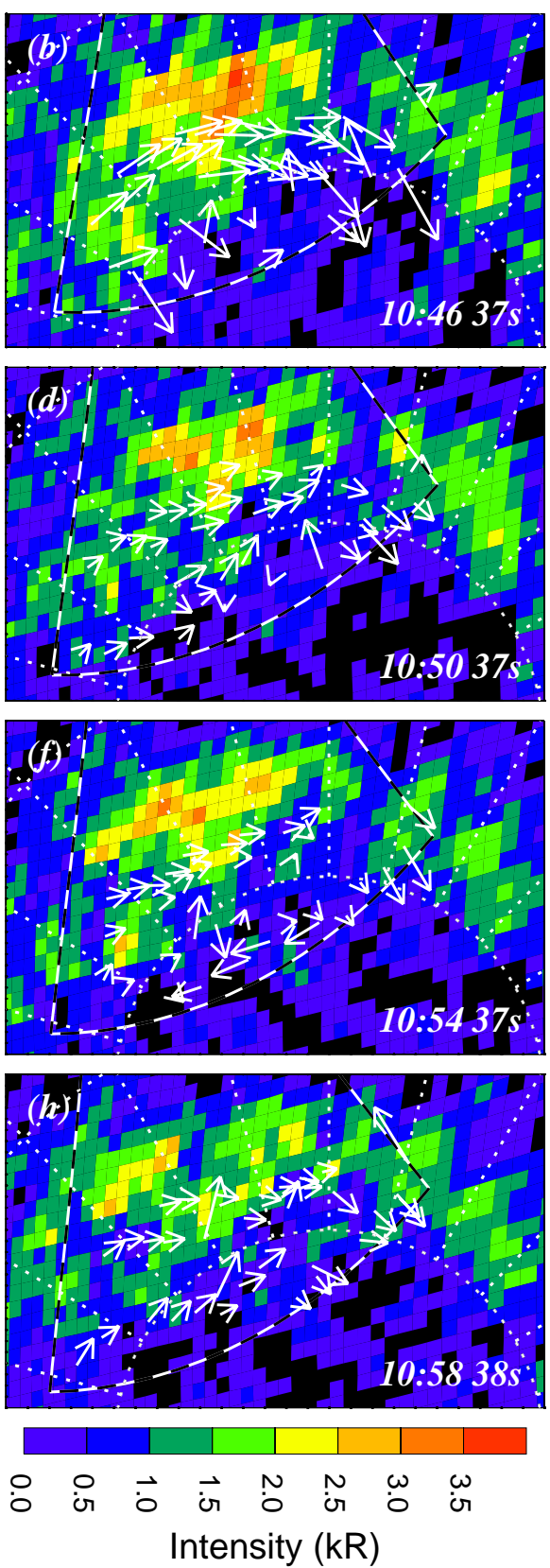

Fig. 4. CUTLASS Hankasalmi line-ofsight velocity scans and Polar VIS images for the interval 1046:20-1058:20 UT. Format as for Fig. 2. the right hand side of Figs. 2-4, and are also overlaid with the same beamswung velocities. The nightside (not shown) shows very little optical activity, suggesting that reconnection is confined to the dayside in the period 1000-1100 UT. In Fig. 2a, in the scan starting at 1014:31 UT, before the onset of the first reconnection-associated flow enhancement, the radar observes sunward, return flow in its easternmost beams, with some evidence of weak antisunward flow near the noon meridian. The corresponding auroral image shows only a weak oval, with intensities below $2 \mathrm{kR}$ and confined mainly to an arc along $\sim 78^{\circ}$ MLAT. As the first episode of flux transfer develops between 1018:4-1026:31 UT, the lower three rows of Fig. 2 show a strengthening auroral oval with a region of enhanced FUV emission appearing at 12$13 \mathrm{MLT}, 77^{\circ}-79^{\circ}$ MLAT (approximately $300 \mathrm{~km} \times 300 \mathrm{~km}$ ) collocated with beams 5 and 6 of the radar, reaching intensities of $3 \mathrm{kR}$. The flows enhance, in concert with the FUV emissions, the brightest patch of which lies at the turning point of the flow, which both strengthens and exhibits increased curvature. Strong antisunward flows are seen near magnetic local noon at high latitudes, and these correspond to the poleward moving enhanced flow velocity presented in Fig. 1 after 1020 UT. The pulsed flow begins at $79^{\circ}$ MLAT and moves poleward to $82^{\circ}$ MLAT over 8 minutes until it lies 
poleward of the FUV feature. The convection evolves from sunward, azimuthal flow to antisunward flow, across Hankasalmi beams 8 to 5 , and this region of antisunward flow moves eastward during the sequence of scans presented in Fig. 2. The flow is generally westward as well as poleward, in the 'throat' region of the convection pattern, which is consistent with predictions by Cowley and Lockwood (1992) for positive IMF $B_{y}$.

Figure 3 presents a similar view of the developing flows from 1030:43-1042:44 UT, corresponding to the second and third intervals of reconnection-associated flows in Fig. 1. These two flow events are not as clearly distinguished as the first, but again, a strong area of enhanced FUV auroral luminosity (now increasing to over $4 \mathrm{kR}$ ) is accompanied by ionospheric flows with a strong clockwise-directed curvature. The antisunward radar flow measurements lie west and poleward of the centre of the auroral emissions. The centre of the enhanced FUV emissions and the edge of the antisunward flows have migrated duskward compared to the images in Fig. 2, to 13-14 MLT. The footprint of a DMSP spacecraft overpass is indicated in panels $\mathrm{c}$ and $\mathrm{d}$, which will be discussed later.

Figure 4 presents the last sequence of flow and auroral maps during the interval from 1046:20-1058:20 UT, after the IMF has turned northward. The dayside auroral zone evolves back to a low level of FUV emissions during this time, and the flows measured by the CUTLASS radar weaken dramatically between panels a and g. The final panels of Fig. 4 (panels $g$ and $h$ ) closely resemble the first two panels of Fig. 2 , which were measured prior to the reconnection activity, but with the auroral oval displaced slightly equatorward.

\subsection{DMSP F14 overpass}

Several DMSP passes through the radar field of view occurred during the reconnection sequence described above, but only one passed close to the region of enhanced FUV intensity, the footprint shown in Fig. 3c, d. Fig. 3d indicates that the spacecraft skirted just equatorward of the intense FUV emission region, passing closest between 1033:10 and 1033:50 UT. The radar data reveals the overpass to be through a region of sunward flows. This overpass is shown in more detail in relation to the radar f-o-v in Fig. 5, which presents 1-o-s velocity, backscatter power and spectral width for the three $32 \mathrm{~s}$ radar scans which encompass the overflight of the radar data. The radar data can be seen as largely consistent throughout the three scans, although the flow strengthens slightly between Figs. 5a and c. The DMSP spacecraft traverses a region of sunward flow, just equatorward of a high power region of radar backscatter, which lies at the eastern and equatorward edge of the broad spectral width region. The 'cusp-like' enhanced spectral widths (Baker et al., 1995) generally cover both the cusp 'throat' on the western edge and the flow turning point, but only part of the dusk return cell flow. The electron and ion spectrograms associated with the overflight are shown in Fig. 6. As the spacecraft enters the radar field of view, it observes low energy electrons and ions centred around $1 \mathrm{keV}$. As it passes equatorward of the enhanced FUV region, intense, structured electron precipitation is observed. This is the only region of the spectrogram where the electron energy flux dominates that of the ions. The electron precipitation is presumably associated with the FUV aurora, although whether the structuring is temporal, spatial or both is unclear from the data presented here. Subsequently, the spacecraft moves to lower latitudes, and higher energy electrons and ions predominate.

\section{Discussion and conclusions}

The peak FUV emissions above $3.0 \mathrm{kR}$ are constrained to an area less than $500 \mathrm{~km}$ by $500 \mathrm{~km}$. They consistently lie in the region, characterised by the narrow radar spectral widths in Fig. 5, at the turning point of the flows from the dusk cell into the poleward cusp 'throat' region, as measured by the radar. The FUV region also lies equatorward of the region of enhanced velocity flow channels in the cusp 'throat' which are associated with FTEs observed at the magnetopause, and are characterised by broad spectral width in the radar data in Fig. 5. The location of peak FUV emissions is initially centred near noon, but migrates to near 1400 MLT during the interval. This region of bright FUV aurora is consistent with the frequently occurring postnoon 'hot spot' (Liou et al., 1999). The dayside cusp ionosphere connects to a complex arrangement of FACs including upward region 1 (R1) currents on the dusk side of noon, downward R1 currents on the dawn side of noon and cusp/mantle $(\mathrm{C} / \mathrm{M})$ currents slightly poleward of the R1 FACs (e.g. Lu et al., 1995). In a model of polar cap inflation caused by unbalanced dayside reconnection, Siscoe and Huang (1985) predicted that the R1 FACs would maximise at the edge of the 'flux gap' or merging line. This maximum FAC thus lies at the point where the flows turn from towards noon in the dayside portion of the dusk and dawn return flow cells, to poleward into the cusp 'throat' (e.g. Heelis et al. 1976; Weimer, 1995) of the convection pattern as they cross the merging gap. The location of the greatest dusk-side R1 FAC current density was measured by Iijima and Potemra (1978), occurring at 14 MLT, and the FUV peak emission regions are consistent with this. The highly localised and structured peak electron precipitation measured by DMSP, coinciding with enhanced FUV emission, also suggests an upward FAC. The observations presented in this paper thus indicate that the enhanced optical emissions in the FUV range near 12-14 MLT are associated with the R1 FAC on the dusk edge of the merging gap. This R1 FAC is strongly intensified during the dayside reconnection sequence.

Siscoe and Huang (1985) also predicted a widening of the merging gap during an extended dayside reconnection sequence, and this is observed in both the radar flows and the FUV emissions. The eastward shift of the peak FUV region from near 12 MLT to near 14 MLT, between 1026 UT and $1030 \mathrm{UT}$, is consistent with the widening of the merging gap, if the peak FUV region is associated with the upward dusk 
(a) 10:31 55s - 10:32 27s

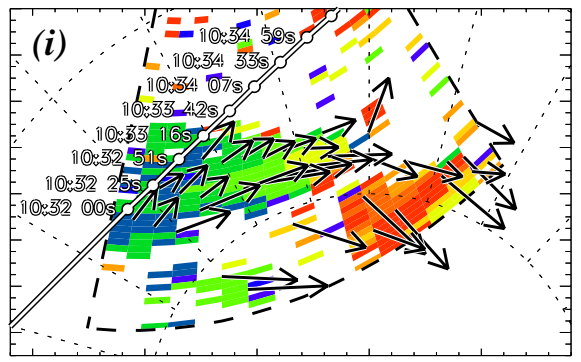

(b) 10:32 31s - 10:33 03s
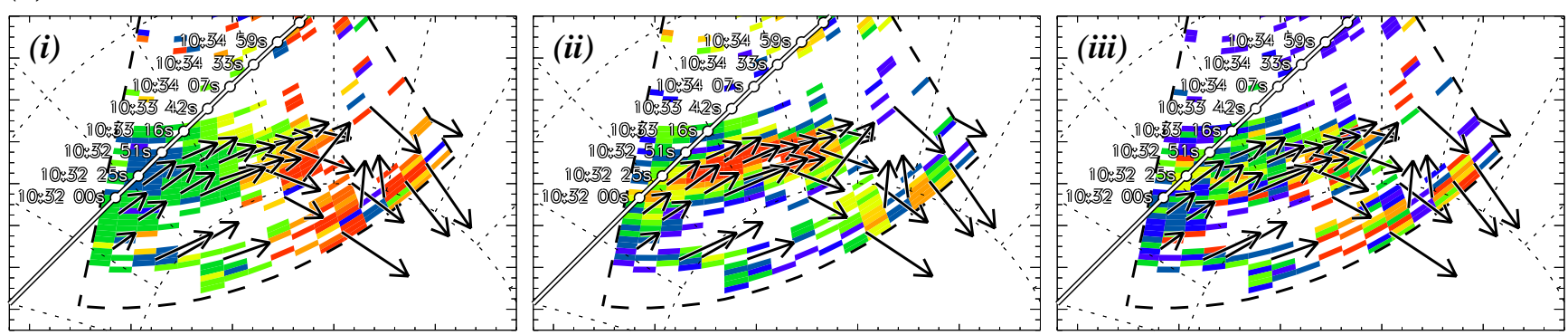

(c) $10: 3307 \mathrm{~s}-10: 3339 \mathrm{~s}$
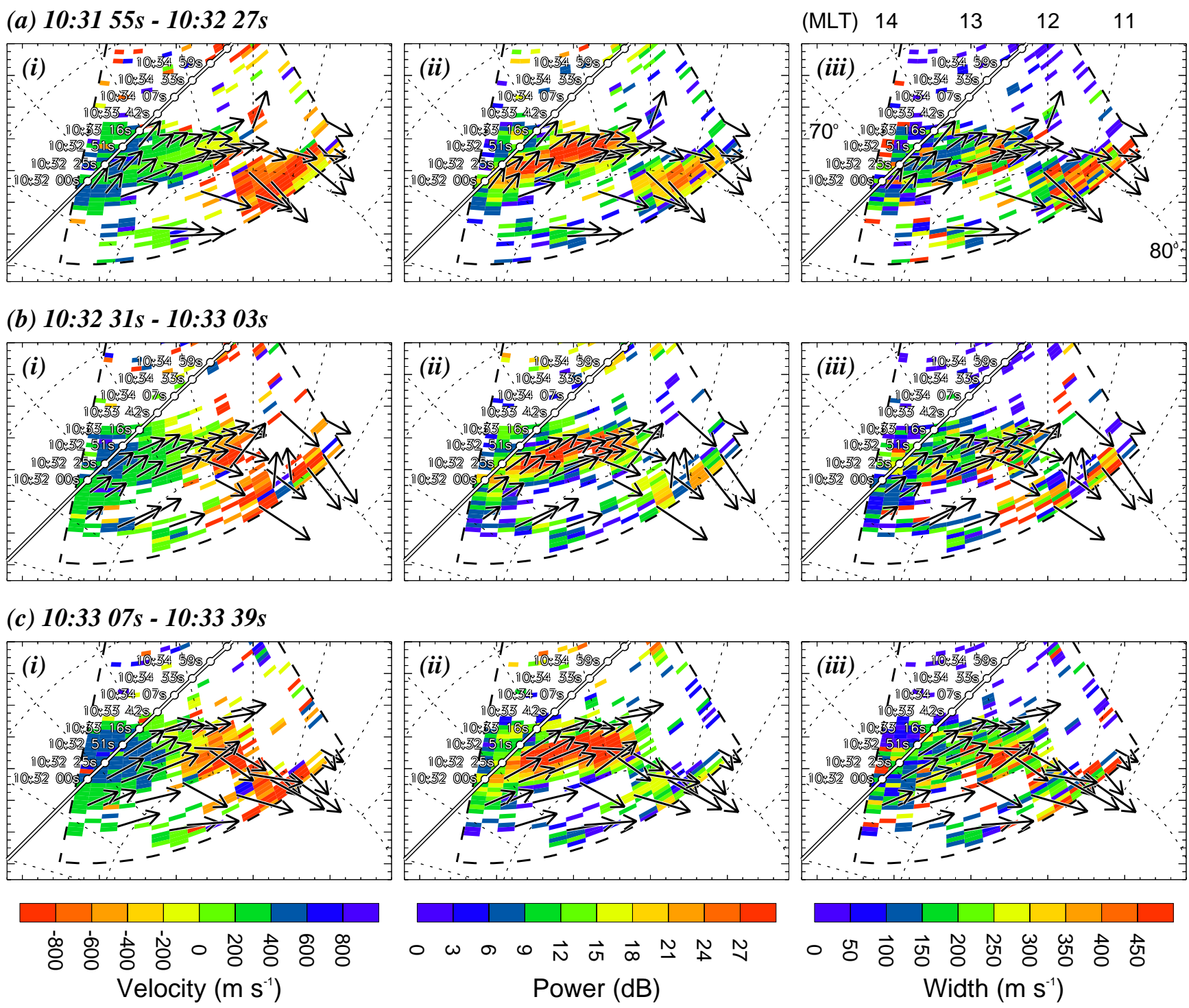
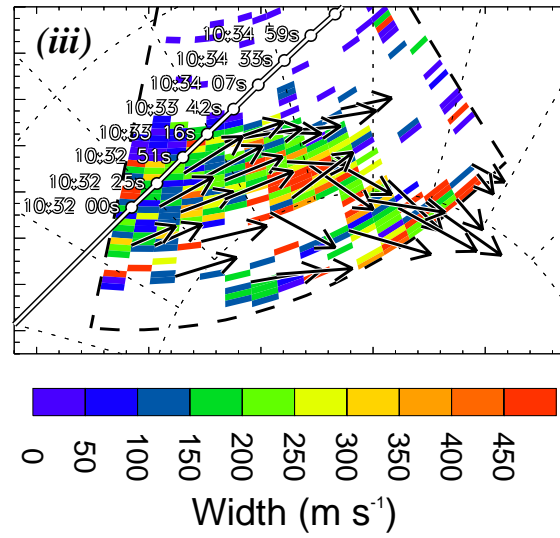

Fig. 5. CUTLASS Hankasalmi scans for three $32 \mathrm{~s}$ scans centred on the DMSP overpass. Beamswung velocity vector estimates and the spacecraft track footprint are overlaid. (a) 1031:55-1032:27 UT (i) line-of-sight velocity (ii) backscattered power (iii) spectral width; (b) similarly for 1032:31-1033:03 UT; (c) similarly for 1033:07-1033:39 UT.

R1 FAC at the gap edge. The measured radar flows also show the gap widening with the region of poleward and westward flow into the polar cap, increasing in width over the 1026 UT to 1030 UT period. As episodes of reconnection are ongoing, the ionospheric plasma velocities rapidly increase in the dusk cell and cusp 'throat'. The merging gap has been observed to expand during the reconnection sequence with the polar cap also expanding, consistent with the predictions of Siscoe and Huang (1985) and Cowley and Lockwood (1992). After the IMF $B_{z}$ turns northward toward the end of the interval, the ionospheric flows decay and the FUV intensity subsides to levels only slightly higher than those prevailing before the $B_{z}$ southward turning.
Acknowledgements. Thanks to J. Sartain at University of Iowa for providing the Polar VIS Earth Camera data, the University of Leicester CUTLASS HF radar team and S. Milan for data visualisation software. For the Equator-S data we thank the Equator-S staff at Max-Planck Institut für Extraterrestrische Physik (MPE), the German Space Operations Centre (GSOC) and T.U. Braunschweig. Equator-S was made possible through grant $500 \mathrm{C} 94024$ of the German Space Agency (DARA). We also thank P. Newell and J. Skura (Applied Physics Lab/Johns Hopkins University) for the DMSP data. D. Neudegg was supported by U.K. PPARC (Particle Physics and Astronomy Research Council) grant GR/L29767. K. A. McWilliams gratefully acknowledges graduate research funding from the Association of Commonwealth Universities of the British Council.

The Editor-in-Chief thanks P. E. Sandholt and C. J. Farrugia for their help in evaluating this paper. 


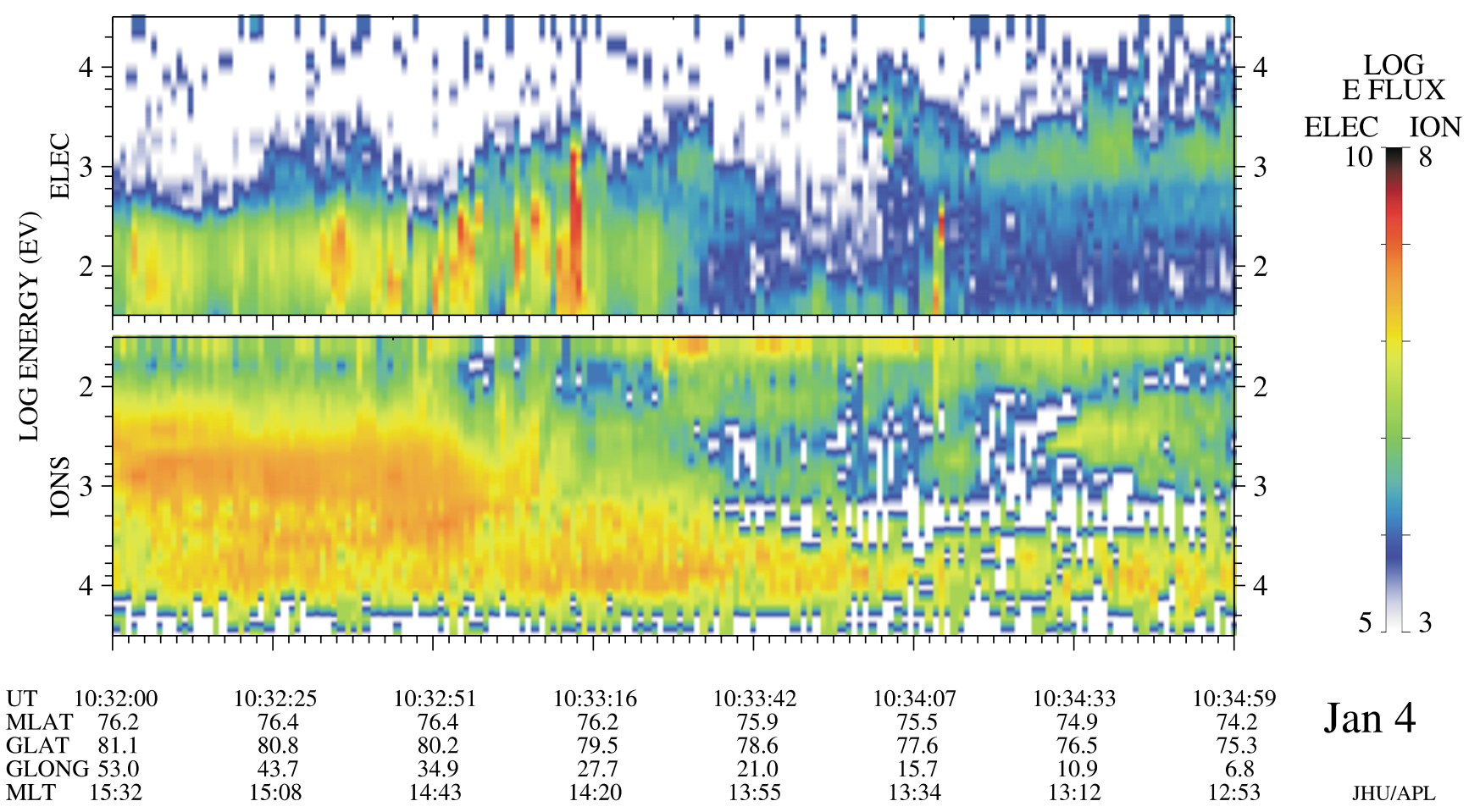

Fig. 6. DMSP spectrogram for the spacecraft overpass in Fig 5. Ion and electron fluxes are presented. Note the inverted energy scale in the ion panel.

\section{References}

Baker, K. B., Dudeney, J. R., Greenwald, R. A., Pinnock, M., Newell, P. T., Rodger, A. S., Mattin, N., and Meng, C.-I., HF radar signatures of the cusp and low-latitude boundary layer, J. Geophys. Res., 100, 7671, 1995.

Cowley, S. W. H., and Lockwood, M., Excitation and decay of solar wind-driven flows in the magnetosphere-ionosphere system, Ann. Geophysicae, 10, 103, 1992.

Cowley, S. W. H., Freeman, M. P., Lockwood, M., and Smith, M. F., The ionospheric signature of flux transfer events, Cluster: Dayside polar cusp, ESA SP-330, ESA Noordwijk, The Netherlands, 105, 1991.

Cowley S. W. H., Magnetosphere-ionosphere interactions - A tutorial review, in 'Magnetospheric current systems' edited by $\mathrm{S}$. Ohtani, R. Fujii, M. Hesse and R. L. Lysak, AGU publications, Washington DC, 2000.

Elphic, R. C., Lockwood, M., Cowley, S. W. H., and Sandholt, P. E., Flux transfer events at the magnetopause and in the ionosphere, Geophys. Res. Lett., 17, 2241, 1990.

Feldman, P. D. and Gentieu, E. P., The ultraviolet spectrum of an aurora 530-1520 Å, J. Geophys. Res., 87, 2453, 1982.

Fornacon, K.-H., Auster, H. U., Georgescu, E., Baumjohann, W., Glassmeier, K.-H., Haerendel, G., Rustenbach, J., Dunlop, M., The magnetic field experiment onboard Equator-S and its scientific possibilities, Ann. Geophysicae, 17, 1521, 1999.

Frank, L. A., Sigwarth, J. B., Craven, J. D., Cravens, J. P., Dolan, J. S., Dvorsky, M. R., Hardebeck, P. K., Harvey, J. D., and Muller, D. W., The visible imaging system (VIS) for the POLAR spacecraft, Space Sci. Rev., 71, 297, 1995.

Glassmeier, K.-H., and Stellmacher, M., Mapping of flux transfer events to the ionosphere, Adv. Space Res. 18, 151, 1996.
Greenwald, R. A., et al., A global view of high-latitude convection, Space Sci. Rev., 71, 763, 1995.

Haerendel, G., Torbert, R. B. and Höfner, H., The Equator-S mission, Ann. Geophysicae, 17, 1499, 1999.

Hardy, D. A., Schmitt, L. K., Gussenhoven, F. J., Yeh, H. C., Schumaker, T. L., Hube, A., and Pantazis, J., Precipitating electron and ion detectors (SSJ/4) for the block 5D/flights 6-10 DMSP satellites: Calibration and data presentation, Report AFGL-TR84-0317, Air Force Geophysics Laboratory, Hanscom Air Force Base, Mass., USA., 1985.

Heelis, R. A., Hanson, W. B., and Burch, J. L., Ion convection velocity reversals in the dayside cleft, J. Geophys. Res., 81, 3803, 1976.

Iijima, T., and Potemra, T. A., Large scale characteristics of fieldaligned-currents associated with substorms, J. Geophys. Res., 83, 599, 1978.

Kan, J. R., Deehr, C. S., Lyu, L. H., and Newell, P. T., Ionospheric signatures of patchy-intermittent reconnection at dayside magnetopause, J. Geophys. Res., 101, 10939, 1996.

Lepping, R. P., et al., The WIND magnetic field investigation, Space Sci. Rev., 71, 207, 1995.

Liou, K., Newell, P. T., Meng, C.-I., Sotirelis, T., Brittnacher, M., and Parks, G., Source regions of 1500 MLT auroral bright spots: simultaneous Polar UV images and DMSP particle data, J. Geophys. Res., 104, 24,587, 1999.

Lu, G., Lyons, L. R., Reiff, P. H., Denig, W. F., de la Beaujardiére, O., Kroehl, H. W., Newell, P. T., Rich, F. J., Opgenoorth, H., Persson, M. A. L., Ruohoniemi, J. M., Friis-Christensen, E., Tomlinson, L., Morris, R. J., Burns, G. B., and McEwin, A., Characterstics of ionospheric convection and field-aligned current in the dayside cusp region, J. Geophys. Res., 100, 11,845, 1995. 
Lockwood, M., Sandholt, P. E., and Cowley, S. W. H., Dayside auroral activity and magnetic flux transfer from the solar wind, Geophys. Res. Lett., 16, 1, 33, 1989.

Lockwood, M. Moen,, J., Cowley, S. W. H., Farmer, A. D., Løvhaug, U. P., Lühr, H., and Davda, V. N., Variability of dayside convection and motions of the cusp/cleft aurora, Geophys. Res. Lett., 20, 1011, 1993.

Lockwood, M., Cowley, S. W. H., Sandholt, P. E., and Løvhaug, U. P., Causes of plasma flow bursts and dayside auroral transients: An evaluation of two models invoking reconnection pulses and changes in the $Y$ component of the magnetosheath field, J. Geophys. Res., 100, 7613, 1995.

McWilliams, K. A., Yeoman, T. K., and Provan, G., A statistical study of dayside pulsed ionospheric flows as seen by the CUTLASS Finland HF radar, Ann. Geophysicae, 18, 445, 2000.

Meier, R. R. and Strickland, D. J., Auroral emission processes and remote sensing, Chap II-3, p37, in Auroral Physics, ed. C.-I. Meng, M. J. Rycroft and L. A. Frank, Cambridge University Press, ISBN 052138049 9, 1991.

Meier, R. R., Conway, R. R., Feldman, P. D., Strickland, D. J., and Gentieu, E. P., Analysis of nitrogen and oxygen far ultraviolet auroral emissions, J. Geophys. Res., 87, 2444, 1982.

Mende, S. B., Klumpar, D. M., Fuselier, S. A., and Anderson, B. J., Dayside auroral dynamics: South Pole - AMPTE/CCE observations, J. Geophys. Res., 103, 6891, 1998.

Milan, S. E., Yeoman, T. K., Lester, M., Thomas, E. C., and Jones, T. B., Initial backscatter occurrence statistics from the CUTLASS HF radars, Ann. Geophysicae, 15, 703, 1997.

Milan, S. E., Lester, M., Greenwald, R. A., and Sofko, G., The ionospheric signature of transient dayside reconnection and the associated pulsed convection return flow, Ann. Geophysicae, 17, 1166, 1999.

Milan, S. E., Lester, M., Cowley, S. W. H., and Brittnacher, M., Convection and auroral response to a southward turning of the IMF: Polar UVI, CUTLASS and IMAGE signatures of transient magnetic flux transfer at the magnetopause, J. Geophys. Res., 105, 15741, 2000.

Neudegg, D. A., Yeoman, T. K., Cowley, S. W. H., Provan, G., Haerendel, G., Baumjohann, W., Auster, U., Fornacon, K.-H. Georgescu,, E., and Owen, C. J., A flux transfer event observed at the magnetopause by the Equator-S spacecraft and in the ionosphere by the CUTLASS HF radar, Ann. Geophysicae, 17, 707, 1999.

Neudegg, D. A., Cowley, S. W. H., Milan, S. E., Yeoman, T. K., Lester, M., Provan, G., Haerendel, G., Baumjohann, W., Nikutowski, B., Büchner, J., Auster, U., Fornacon, K.-H., and Georgescu, E., A survey of magnetopause FTEs and associated flow bursts in the polar ionosphere, Ann. Geophysicae, 18, 416, 2000.
Newell P. T. and Meng, C.-I., Mapping the dayside ionosphere to the magnetosphere according to particle precipitation characteristics, Geophys. Res. Lett., 19, 609-612, 1992.

Øieroset, M., Lühr, H., Moen, J., Moretto, T., and Sandholt, P. E., Dynamical auroral morphology in relation to ionospheric plasma convection and geomagnetic activity: signatures of magnetopause $X$ line dynamics and flux transfer events, J. Geophys. Res., 101, 13275, 1996.

Pinnock, M., Rodger, A. S., Dudeney, J. R., Baker, K. B., Greenwald, R. A., and Greenspan, M., Observations of an enhanced convection channel in the cusp ionosphere, J. Geophys. Res., 98, 3767, 1993.

Pinnock, M., Rodger, A. S., Dudeney, J. R., Rich, F., and Baker, K. B., High spatial and temporal resolution observations of the ionospheric cusp, Ann. Geophysicae, 13, 919, 1995.

Provan, G., Yeoman, T. K., and Milan, S. E., CUTLASS Finland radar observations of the ionospheric signatures of flux transfer events and the resulting plasma flows, Ann. Geophysicae, 16, 1411, 1998.

Provan, G. and Yeoman, T. K., Statistical observations of the MLT, latitude and size of pulsed ionospheric flows with the CUTLASS Finland radar. Ann. Geophysicae, 17, 855, 1999.

Provan, G., Yeoman, T. K., and Cowley, S. W. H., The influence of the IMF $B_{y}$ component on the location of pulsed flows in the dayside ionosphere observed by an HF radar, Geophys. Res. Lett., 26, 521, 1999.

Rodger, A. S. and Pinnock, M., The ionospheric response to FTEs: the first few minutes, Ann. Geophysicae, 15, 685, 1997.

Ruohoniemi, J. M., Greenwald, R. A., Baker, K. B., Villain, J.P., Hanuise, C., and Kelley, J. D., Mapping high latitude plasma convection with coherent HF radars, J. Geophys. Res., 94, 13463, 1989.

Sandholt, P. E., Farrugia, C. J., Stauning, P., Cowley, S. W. H., and Hansen, T., Cusp/cleft auroral forms and activities in relation to ionospheric convection: Responses to specific changes in solar wind and interplanetary magnetic field conditions, J. Geophys. Res., 101, 5003, 1996.

Siscoe, G. L. and Huang, T. S., Polar cap inflation and deflation, J. Geophys. Res., 90, 543, 1985.

Villain, J. P., Greenwald, R. A., Baker, K. B., and Ruohoniemi, J. M., HF radar observations of $\mathrm{E}$ region plasma irregularities produced by oblique plasma streaming, J. Geophys. Res., 92, 12327, 1987.

Weimer, D. R., Models of high-latitude electric potentials derived with a least error fit of spherical harmonic coefficients, J. Geophys. Res., 100, 19595, 1995.

Wright, A., Transfer of magnetosheath momentum and energy to the ionosphere along open field lines, J. Geophys. Res., 101, 13169, 1996. 